\title{
I I 13 amplification status and human papillomavirus in relation to pl6 expression defines two distinct etiologies of head and neck
}

\section{tumours}

\author{
CCR Ragin ${ }^{1,2,3}$, E Taioli' ${ }^{2,3}$, JL Weissfeld ${ }^{2,3}$, JS White ${ }^{1,2,3}$, KM Rossie $^{4}$, F Modugno ${ }^{2,3}$ and SM Gollin ${ }^{* 1,3}$ \\ 'Department of Human Genetics, University of Pittsburgh Graduate School of Public Health, 130 DeSoto Street, Pittsburgh, PA 1526I, USA; \\ ${ }^{2}$ Department of Epidemiology, University of Pittsburgh Graduate School of Public Health, Pittsburgh, PA 15261, USA; ${ }^{3}$ The University of Pittsburgh Cancer \\ Institute, Pittsburgh, PA 15232, USA; ${ }^{4}$ Department of Oral Medicine and Pathology, School of Dental Medicine, Pittsburgh, PA 15232, USA
}

Two distinct etiologies of head and neck squamous cell carcinoma (HNSCC) have been proposed, DNA damage owing to tobacco and alcohol exposure and human papillomavirus (HPV) oncogene-mediated transformation. Common genetic alterations in HNSCC include TP53 mutations, I Iql3 amplification (amp) and CDKN2A/pl6 mutations or promoter methlyation. However, in HPV + HNSCC it is frequent to observe wild-type TP53 and expression of $\mathrm{P} \mid 6$. The relationship of this unusual pattern with I I q 3 amp has not been tested. In a retrospective study on I 25 HNSCC patients, only 17\% (five out of 30) of HPV + vs 44\% (39 out of 89) of HPV - tumours expressed I I q 3 amp (adjusted odds ratio $(\mathrm{OR})=0.2,95 \%$ confidence interval $(\mathrm{Cl})=0 . \mathrm{I}-0.6)$. A subpopulation of tumours $(n=69)$ were classified according to the three molecular markers, TP53, p 6 and I I q 3 amp. In addition to wild-type TP53, and pl6 expression, HPV + tumours were more likely not to be amplified at I I q I3 (OR =6.5, 95\% Cl= I.8-23.9). As HPV + HNSCC lack the genetic alterations which are common in other tumours, we hypothesise that HPV infection may represent an early event in the HNSCC carcinogenic process, thus suggesting a distinct molecular pathway.

British Journal of Cancer (2006) 95, |432- |438. doi:I0.1038/sj.bjc.6603394 www.bjcancer.com

Published online 26 September 2006

(c) 2006 Cancer Research UK

Keywords: HPV; I IqI3; gene amplification; CDKN2A/p I6; head and neck cancer; TP53

Although the majority of cases of head and neck squamous cell carcinoma (HNSCC) are attributed to tobacco and alcohol consumption (Blot et al, 1988; Merletti et al, 1989; Franceschi et al, 1990; Franceschi et al, 1999), morphologic signs of human papillomavirus (HPV) infection and detection of the viral antigens in oral squamous cell carcinomas were first reported in 1983 (Syrjanen et al, 1983). Increasing evidence from large case - control studies of HPV prevalence in head and neck tumours suggests that this virus may be an additional independent risk factor for a subset ( $\sim 25 \%$ ) of HNSCC (Smith et al, 1998; Gillison et al, 2000; Herrero et al, 2003).

Head and neck squamous cell carcinoma frequently carries numerous genetic alterations, such as mutations, chromosomal losses, gains and amplifications (amp) (Gollin, 2001). Common genetic alterations in HNSCC involve TP53, CDKN2A/p16 and chromosomal band 11q13. Amplification of $11 \mathrm{q} 13$ is among the most common sites of gene amplification, observed in a number of cancers (Schraml et al, 1999), and in approximately $45 \%$ of HNSCC

*Correspondence: Dr SM Gollin; Department of Human Genetics, University of Pittsburgh Graduate School of Public Health, 130 Desoto Street, Pittsburgh, PA | 526I, USA;

E-mail: sgollin@hgen.pitt.edu

Received 2 June 2006; accepted 29 August 2006; published online 26 September 2006
(Lese et al, 1995; Schuuring, 1995; Gollin, 2001). A number of putative oncogenes map to this region; among them, CCND1 (cyclin D1) is thought to play a role in tumorigenesis. Cyclin D1 is an important cell cycle protein that binds cyclin-dependent kinase (CDK) 4 or 6 to phosphorylate and inactivate the RB1 protein thus driving the cell from G1 into S-phase. Therefore, overexpression of cyclin D1 may lead to deregulate cell cycling from G1 to S-phase and may result in a selective growth advantage for the affected cell.

$C D K N 2 A / p 16$ opposes cyclin D1 function by negatively regulating RB1 phosphorylartion and a genetic (loss of heterozygosity $(\mathrm{LOH})$ ) or epigenetic (promoter methylation) alteration in this gene is frequently observed, resulting in a lack of p16 expression in most HNSCC (Weber et al, 2003). TP53, also is a frequently mutated tumour-suppressor gene in a number of cancers, including about $45 \%$ of HNSCC (Sidransky, 1995).

In contrast to most HNSCC, HPV-positive tumours are more likely to have wild-type TP53. Human papillomavirus-infected cells accomplish $G_{1}$ to $S$-phase transition through the targeted degradation of $\mathrm{pRb}$ by the viral E7 oncoprotein and consequently, $C D K N 2 A / p 16$ is overexpressed. Correlations between genetic alterations at TP53, 11q13 and p16 expression with HPV have not been evaluated. We report a retrospective study examining the association of HPV with these molecular risk factors (TP53 mutation, p16 protein expression and $11 \mathrm{q} 13 \mathrm{amp}$ ) in patients with first primary head and neck tumours. 


\section{MATERIALS AND METHODS}

\section{Study population}

The study population $(N=185)$ included patients undergoing surgical resection of their tumours between September 1992 and February 1997, following informed consent under a protocol approved by the University of Pittsburgh Biomedical Institutional Review Board. Patients with recurrent tumours, second primaries and metastatic tumours (lymph node and distant) at the time of enrollment were excluded from this analysis $(n=58)$. The remaining subjects $(n=127)$, with first primary tumours were enrolled. Human papillomavirus could be tested in only 125 of 127 tumours; therefore, the number of patients included in this analysis was 125 .

\section{Head and neck database}

The head and neck database was established by CCRR, JSW and JLW in June 2004. Information, including demographics, smoking and alcohol use, family history, tumour site, clinical characteristics of the initial primary tumour and subsequent tumours, follow-up data (such as disease outcome and time to next disease occurrence) through May 2004 were obtained from the University of Pittsburgh Tumor Registry. Patients' clinical and demographic information from the Tumor Registry was re-verified from each patient's original deidentified and coded questionnaires, pathology and surgical reports. All data from the Tumor Registry was combined with the corresponding patient's laboratory data (i.e. TP53 mutation, 11q13 amp, p16 expression and HPV status and genotype) to form the head and neck database. This database contains clinical, treatment and follow-up information for the first surgical resection at the time of enrollment and all subsequent resections for all patients enrolled in the study.

Smoking status was defined as follows: never smoker (never smoked), current smoker (recorded as an ever smoker who had not quit at the time of enrollment), former smoker (quit smoking at least 1 month before enrollment in the study). Alcohol use was defined as follows: never drinker (never consumed alcohol), current drinker (had not quit alcohol consumption at the time of enrollment) and former drinker (quit alcohol consumption before enrollment). For the duration of alcohol use, each patient was categorised as never (never consumed alcohol), short-term (consumed alcohol socially or for less than 10 years), or longterm (consumed alcohol for 10 years or more, irrespective of consumption habit) users. Tumour site, histology, stage and grade were classified according to the American Joint Committee on Cancer (AJCC) ICD9 codes, ICD-morphology, stage and grade classification, respectively. Sites of the oral cavity included cheek, retromolar area, alveolar ridge, oral tongue, palate, floor of mouth and overlapping lesions of other and unspecified parts of the mouth. The oropharynx included sites involving the base of tongue, soft palate, tonsil and overlapping lesions of the oral cavity and pharynx. Analyses of TP53 mutation status (Law et al, 1995) and (Gollin et al, unpublished data), p16 immunohistochemistry (unpublished data) and 11q13 amp (Shuster et al, 2000; Lese et al, 1995) were performed in earlier unpublished studies unless otherwise noted. Briefly, TP53 mutation status was determined by automated sequencing of exons 5-8, p16 immunohistochemistry was performed on paraffin sections of formaldehydefixed tissue using a monoclonal antibody to full length human p16 protein (Vector Labs, Burlingame, CA, USA). Cells were considered p16-positive if more than $5 \%$ of cells in a tumour island or mucosal surface stained visibly stronger than the negative control. When more than $5 \%$ of the cells were stained weakly, the result was considered to be weakly positive for p16. Amplification of $11 \mathrm{q} 13$ was assessed using fluorescence in situ hybridisation
(FISH) probes for FGF3/INT2, FGF4/HST1 or CCND1 (Lese et al, 1995; Shuster et al, 2000).

\section{Human papilloma virus testing and genotyping}

Extracted DNA was available from 125 tumours. Polymerase chain reaction (PCR) amplification of a $\beta$-globin gene fragment was performed using the PCO4 and GH20 primers (Saiki et al, 1986) to confirm that the extracted DNA was amplifiable. All samples were positive for the $\beta$-globin amplicon $(n=125)$. Human papillomavirus status was determined by a nested real-time PCR assay using consensus HPV primers PGMY09/11/HMB01 (Gravitt et al, 2000) and GP5 $+16+$ primers (de Roda Husman et al, 1995). DNA amplification was performed using the LightCycler ${ }^{\circledR}$ FastStart DNA Master ${ }^{\text {PLUS }}$ SYBR Green I kit on a LightCycler ${ }^{\mathbb{R}} 2.0$ system (Roche Diagnostics, Indianapolis, IN, USA). All DNA amplification reactions were set up according to the manufacturer's protocol (using $3 \mathrm{mM} \mathrm{MgCl}_{2}$ and $0.3 \mu \mathrm{M}$ each PGMY09/11/HMB01 primers (for the primary PCR reaction) or $1.0 \mu \mathrm{M}$ each GP5 + /GP6+ primers (for the nested PCR reaction)) and were performed in a separate room from that used for the DNA amplification steps. For all HPV-positive samples from the previously described PCR protocol, confirmation of the appropriately sized amplicon was carried out by running an aliquot of each sample on a $10 \%$ PAGEr ${ }^{\circledR}$ polyacrylamide gel (Cambrex Bio Science, Rockland, ME, USA), at 250 volts for $55 \mathrm{~min}$. The gel was stained with the highly sensitive GelStar ${ }^{\circledR}$ nucleic acid stain (Cambrex Bio Science, Rockland, ME, USA) and the $150 \mathrm{bp}$ GP5 + $/ 6+$ amplicon was visualised using a Clare Chemical Dark Reader transilluminator (Clare Chemical Research, Dolores, CO, USA).

HPV genotyping was performed using the Linear Array HPV Genotyping kit (Roche Diagnostics, Indianapolis, IN, USA). Briefly, the assay involved amplification of samples by PCR using a master mix which contained biotin-labelled primers for $33 \mathrm{HPV}$ genotypes $(6,11,16,18,26,31,33,35,39,40,42,45,51,52,53,55,56,59,61$, $62,64,66,68,69,70,72,73$ (MM9), 81, 82(MM4), 83(MM7), 84(MM8), IS39 and CP6108) as well as the human $\beta$-globin gene. The PCR products were chemically denatured and hybridised to linear array strips which contained specific and one cross-reactive oligonucleotide probes for the HPV genotypes listed above as well as a high and low concentration of a $\beta$-globin probe. The specific genotypes were visualised using streptavidin-horseradish peroxidase conjugate and a substrate solution containing hydrogen peroxide and $3,3^{\prime}, 5,5^{\prime}$-tetramethylbenzidine which yielded a blue precipitate at the probe positions where hybridisation occurred.

\section{Pyrosequencing}

Ten samples, which were positive by nested-PCR, were not able to be genotyped using the Linear Array kit because they were below the detectable limit of the assay. Human papillomavirus genotyping of these samples was accomplished by pyrosequencing (Biotage, Foxboro, MA, USA) performed according to the manufacturer's instructions. Briefly, the nested PCR was performed as described above. The GP6 + primer was biotinylated at the $3^{\prime}$-end. The PCR product was denatured to obtain single stranded DNA, followed by pyrosequencing using the GP5 + as the sequencing primer. The following dispensation order was used GCACTACGCTAGCTACTACTGACTGACTGACTGACTGACTGAC TGACTGACTGACTGACTGACTG. To identify the HPV genotype, sequencing results were aligned with the expected sequences for the 37 most common HPV genotypes or blasted against HPV sequences in the NCBI database.

\section{Statistical analyses}

Clinical and laboratory risk factors for the study population were extracted from our head and neck database and imported to a 
statistical software package for analysis. Statistical analyses were performed using the Intercooled STATA (version 8.2) software (StataCorp. LP, College Station TX, USA). Factors associated with HPV status were selected based on cross-tabulations and univariate logistic regression analyses. Cross-tabulations were analysed using the $\chi^{2}$ test or Fisher's exact test, where appropriate. Logistic regression was used to perform the analyses of associations between demographic, clinical and pathologic variables with HPV status. Crude odds ratio (OR) were first calculated. Univariate analyses for the association of selected variables with $11 \mathrm{q} 13 \mathrm{amp}$ status were performed in the subset of HPV-negative subjects to identify possible confounding factors of association. Potential confounders were identified based on $P$-values $\leqslant 0.1$. Logistic regression was used to calculate the relative odds of HPV status with 11q13 amp after adjusting for the potential confounders (age, tumour stage and site).

\section{RESULTS}

\section{Study population demographics}

Table 1 summarises the patient demographics. Approximately $64 \%$ ( 80 out of 125 ) of the patients were males and $36 \%$ (45 out of 125) were females. The majority of patients were current smokers $(n=76,61 \%)$. The majority of the study population $(65 \%)$ was dead by the last follow-up (May 2004). Our study population ranged in age from 18 to 92 years; the median age at diagnosis was 63 years, and the median age at death was 67 years.

\section{Human papillomavirus prevalence and genotype in tumour specimens}

Twenty-four percent (30 out of 125) of the tumours were positive for HPV. All HPV-positive tumours contained HPV16 whereas two out of $30(7 \%)$ were coinfected with other HPV types. One had an additional low-risk HPV type 11 and the other had an additional high-risk HPV type 33 and possibly 52 (a positive hybridisation signal for cross-reactive HPV33 probe on the HPV linear array genotyping strip could not rule out the presence of HPV52) (Table 1).

\section{Distribution of tumour human papillomavirus status according to patient characteristics}

The majority of tumours occurred in the oral cavity (91 out of 125 , 73\%). Human papillomavirus-positive tumours occurred at various sites throughout the oral cavity and pharynx (data not shown). Approximately $20 \%$ (18 out of 91 ) of tumours from the oral cavity were found to be HPV-positive, whereas a slightly higher proportion of HPV-positive tumours were observed in the oropharynx (35\% (12 out of 34$)$. When stratified by smoking status, seven HPV-positive tumours from the oropharynx of current smokers occurred in the base of tongue (3), soft palate (2), tonsil (1) and an overlapping lesion of the oropharynx (1). In contrast, the five HPV-positive tumours from the oropharynx of nonsmokers and former smokers occurred in the tonsil (3) and base of tongue (2) only.

Analyses of factors associated with a positive HPV status are summarised in Table 2. Human papillomavirus-positive tumours were less likely to occur in older individuals ( $<55$ years. $40 \%$ were HPV-positive $v s \geqslant 55$ years, 19\% were HPV-positive: adjusted $\mathrm{OR}=0.3,95 \%$ confidence interval $(\mathrm{CI})=0.1-0.8)$, and were less likely to carry amplified genes in chromosomal band 11q13. After adjusting for age, tumour site and stage, $11 \mathrm{q} 13 \mathrm{amp}$ status was still statistically associated with HPV status, with only $17 \%$ (five out of 30) of HPV-positive tumours vs 44\% (39 out of 89) of HPVnegative tumours having $11 \mathrm{q} 13$ amp (adjusted $\mathrm{OR}=0.2,95 \%$ $\mathrm{CI}=0.1-0.6)$.
Table I Patient characteristics $(n=125)$

\begin{tabular}{|c|c|c|}
\hline Characteristic & $N$ & Percent (\%) \\
\hline \multicolumn{3}{|l|}{ Age (years) } \\
\hline$<35$ & 3 & 2.40 \\
\hline $36-45$ & 9 & 7.20 \\
\hline $46-55$ & 18 & 14.40 \\
\hline $56-65$ & 43 & 34.40 \\
\hline $66-75$ & 37 & 29.60 \\
\hline $76-85$ & 13 & 10.40 \\
\hline$>85$ & 2 & 1.60 \\
\hline \multicolumn{3}{|l|}{ Gender } \\
\hline Male & 80 & 64.00 \\
\hline Female & 45 & 36.00 \\
\hline \multicolumn{3}{|l|}{ Race } \\
\hline Caucasian & 117 & 93.60 \\
\hline Other & 8 & 6.40 \\
\hline \multicolumn{3}{|l|}{ Vital status } \\
\hline Alive & 44 & 35.20 \\
\hline Dead & 81 & 64.80 \\
\hline \multicolumn{3}{|l|}{ Tobacco exposure } \\
\hline Never & 13 & 10.40 \\
\hline Former & 36 & 28.80 \\
\hline Current & 76 & 60.80 \\
\hline \multicolumn{3}{|l|}{ Alcohol duration/years } \\
\hline Never & 18 & 14.40 \\
\hline Social & 3 & 2.40 \\
\hline $2-10$ & 6 & 4.80 \\
\hline $11-30$ & 33 & 26.40 \\
\hline $31-50$ & 53 & 42.40 \\
\hline$>50$ & 12 & 9.60 \\
\hline \multicolumn{3}{|l|}{ HPV status } \\
\hline Negative & 95 & 76.00 \\
\hline HPVI6 & 28 & 22.40 \\
\hline HPVI6 \& II & 1 & 0.80 \\
\hline HPVI 6, 33 \& $(52)^{\mathrm{a}}$ & । & 0.80 \\
\hline \multicolumn{3}{|l|}{ Family history cancer } \\
\hline No & 62 & 49.60 \\
\hline Yes & 63 & 50.40 \\
\hline \multicolumn{3}{|l|}{ Tumour stage } \\
\hline I & 21 & 16.80 \\
\hline$\|$ & 28 & 22.40 \\
\hline III & 27 & 21.60 \\
\hline IV & 49 & 39.20 \\
\hline \multicolumn{3}{|l|}{ Subsequent tumour(s) } \\
\hline No & 61 & 48.80 \\
\hline Yes & 64 & 51.20 \\
\hline Total & 125 & 100.00 \\
\hline
\end{tabular}

Abbreviation: HPV = human papillomavirus. ${ }^{a}$ Unable to rule out HPV52 owing to cross-reactivity of the HPV33 probe.

We evaluated the pattern of tobacco and alcohol risk behaviours by HPV status. Although the majority of patients from both the HPV-positive and negative groups were ever smokers and ever drinkers (77 and $80 \%$, respectively), these patients were no more likely to be HPV-positive than those who never smoked or consumed alcohol $(\mathrm{OR}=0.8,95 \% \mathrm{CI}=0.1-7.8)$. However, no statistical interaction between alcohol and drinking habits with HPV-positivity was observed.

Individuals with HPV-positive tumours were less likely to have subsequent tumours, either recurrences, metastases or new 
Table 2 Association of patient/tumour characteristics with HPV status

Any HPV subtype

\begin{tabular}{|c|c|c|c|c|}
\hline Characteristics & No. positive $(n=30)$ & No. negative $(n=95)$ & Unadjusted OR (95\% Cl) & Adjusted $O R^{a}(95 \% \mathrm{Cl})$ \\
\hline$<55$ & 12 & 18 & 1.0 (referent) & \\
\hline$\geqslant 55$ & 18 & 77 & $0.4(0.1-0.9)$ & $0.3(0.1-0.8)$ \\
\hline \multicolumn{5}{|l|}{ Gender } \\
\hline Male & 23 & 57 & 1.0 (referent) & \\
\hline Female & 7 & 38 & $0.5(0.2-1.1)$ & $0.5(0.2-1.3)$ \\
\hline Caucasian & 29 & 88 & I.0 (referent) & \\
\hline Other & । & 7 & $0.4(0.1-3.7)$ & $0.2(0.02-2.2)$ \\
\hline \multicolumn{5}{|l|}{ Tobacco exposure } \\
\hline Never & 4 & 9 & $1.7(0.5-6.1)$ & $1.7(0.4-6.7)$ \\
\hline Former & 10 & 26 & $1.4(0.6-3.6)$ & $2.4(0.8-6.6)$ \\
\hline Current & 16 & 60 & 1.0 (referent) & \\
\hline \multicolumn{5}{|l|}{ Alcohol exposure } \\
\hline \multicolumn{5}{|l|}{ Alcohol duration } \\
\hline Never user & 4 & 14 & I.0 (referent) & \\
\hline Short-term user & 3 & 6 & $1.8(0.3-10.3)$ & $1.3(0.2-8.4)$ \\
\hline Long-term user & 23 & 75 & I.I $(0.3-3.6)$ & $0.9(0.3-3.2)$ \\
\hline \multicolumn{5}{|c|}{ Combined tobacco and alcohol exposure } \\
\hline Ever/Ever & 23 & 76 & 1.0 (referent) & \\
\hline Never/Ever & 3 & 5 & $2.0(0.4-8.9)$ & $1.8(0.4-8.6)$ \\
\hline Ever/Never & 3 & 10 & $1.0(0.3-3.9)$ & $1.3(0.3-5.6)$ \\
\hline Never/Never & I & 4 & $0.8(0.1-7.8)$ & $0.8(0.1-8.3)$ \\
\hline \multicolumn{5}{|l|}{ Family cancer history } \\
\hline No & 13 & 49 & 1.0 (referent) & \\
\hline Yes & 17 & 46 & $1.4(0.6-3.2)$ & $1.3(0.6-3.2)$ \\
\hline \multicolumn{5}{|l|}{ Tumour grade } \\
\hline Well & 8 & 24 & 1.0 (referent) & \\
\hline Moderate & 17 & 52 & $1.0(0.4-2.6)$ & $1.0(0.3-2.8)$ \\
\hline Poor & 3 & 11 & $0.8(0.2-3.7)$ & $0.7(0.1-3.2)$ \\
\hline Unknown & 2 & 8 & - & - \\
\hline \multicolumn{5}{|l|}{ Tumour stage } \\
\hline$|\&| \mid$ & 10 & 39 & 1.0 (referent) & \\
\hline III \& IV & 20 & 56 & $1.4(0.6-3.3)$ & $1.4(0.6-3.5)$ \\
\hline \multicolumn{5}{|c|}{ Recurrent, metastatic or new primary tumours } \\
\hline No & 21 & 41 & 1.0 (referent) & \\
\hline Yes & 9 & 54 & $0.4(0.2-0.9)$ & $0.4(0.2-1.0)$ \\
\hline
\end{tabular}

Abbreviations: $\mathrm{Cl}$, confidence interval; HPV, human papillomavirus; OR, odds ratio. ${ }^{\mathrm{a}}$ Adjusted for age, site and stage, where appropriate.

primaries (adjusted $\mathrm{OR}=0.4,95 \% \mathrm{CI}=0.2-1.0$ ). Subsequent tumours that developed in HPV-positive patients $(33 \%, 10$ out of 30) were confined to head and neck sites. In contrast, among patients with HPV-negative tumours, 57\% (54 out of 95) developed recurrences, metastases or new primaries at head and neck sites, as well as other sites throughout the body.
A higher proportion of HPV-positive tumours occurred in the oropharynx. Forty percent (12 out of 30 ) of HPV-positive tumours compared to $23 \%$ (22 out of 95 ) of HPV-negative tumours occurred in the oropharynx (adjusted $\mathrm{OR}=2.4,95 \% \mathrm{CI}=1.0-5.8$ ). A high tumour stage (stage III \& IV: adjusted OR $=1.4,95 \%$ $\mathrm{CI}=0.6-3.5$ ) and family history of cancer (adjusted $\mathrm{OR}=1.3,95 \%$ 
$\mathrm{CI}=0.6-3.2)$ were also more likely to be associated with HPVpositive tumours, but none of these associations were statistically significant.

\section{Human papillomavirus and 11q13 amplification status according to tumour site}

Amplification status at chromosomal band 11q13 was available for 119 tumours from our study population. Approximately 37\% (44 out of 119) were amplified at 11q13. Figure 1 shows the frequency of $11 \mathrm{q} 13 \mathrm{amp}$ stratified by tumour site and HPV status. Overall, we detected a lower prevalence of $11 \mathrm{q} 13 \mathrm{amp}$ in the HPV-positive tumours than in the HPV-negative group (17 vs 44\%, respectively, Fisher's exact $P=0.009$ ). In the oral cavity, $22 \%$ of the HPVpositive tumours were amplified at $11 \mathrm{q} 13$, whereas $39 \%$ of the HPV-negative tumours had 11q13 amp (Fisher's exact $P=0.270$ ). In the oropharynx, a significantly smaller proportion of HPVpositive tumours had 11q13 amp when compared with HPVnegative tumours (8\% HPV-positive vs 60\% HPV-negative, Fisher's exact $P=0.008$ ).

\section{TP53 mutation status, p16 expression and 11q13 amplification status in human papillomavirus-positive tumours}

In a subset of tumours $(n=69)$ for which data on all three molecular markers were available (i.e. TP53 mutation status, p16 expression and 11q13 amp status), their associations with HPV status was assessed (Table 3). TP53 mutations were less likely to occur in the HPV-positive HNSCC (adjusted OR $=0.4,95 \%$ $\mathrm{CI}=0.0-3.1)$. As expected, HPV-positive tumours were more likely to express p16 (adjusted $\mathrm{OR}=3.0,95 \% \mathrm{CI}=0.9-9.7$ ). Sixty percent (nine out of 15) of the HPV-positive tumours exhibited high expression of p16 whereas 33\% (18 out of 54) of HPVnegative tumours expressed high levels of p16.

We classified the subpopulation according to combined p16 expression, TP53 mutation status and $11 \mathrm{q} 13 \mathrm{amp}$ status. Class II included tumours that carried wild-type TP53, expressed p16 and was not amplified at 11q13, class III included tumours that also carried wild-type TP53 and expressed p16 but were amplified at chromosomal band $11 \mathrm{q} 13$ and class I tumours were those with all other combinations of TP53 mutation status, p16 expression and $11 \mathrm{q} 13$ amp status. Human papillomavirus-positive tumours were more likely not to be amplified at $11 \mathrm{q} 13$ and simultaneously overexpress p16 and contain wild-type TP53 (class II: adjusted $\mathrm{OR}=6.5,95 \% \mathrm{CI}=1.8-23.9$ ). The tumours that contained wildtype TP53 overexpressed p16, but those with 11q13 amp were less likely to be HPV-positive than those without $11 \mathrm{q} 13 \mathrm{amp}$ and were no different from all other tumours (class III: $\mathrm{OR}=0.9,95 \%$ $\mathrm{CI}=0.1-8.9)$.

\section{DISCUSSION}

This retrospective study of 125 patients with first primary head and neck tumours evaluated the association between tumour HPV status and patient demographics, clinical risk factors and amplification status at chromosomal band 11q13. We further evaluated the relationship between genetic alterations: TP53 mutation status, $11 \mathrm{q} 13 \mathrm{amp}$ and $\mathrm{p} 16$ protein expression in a subpopulation of 69 unselected tumours. Our analysis shows that along with wild-type TP53 and p16 overexpression, HPV-positive tumours were less likely to carry gene amplification of chromosomal band 11q13, which further defines the characteristic of HPV-positive head and neck tumours and suggests a distinct molecular pathway for HNSCC development.

The relationship between LOH at TP53, 11q13 amp and HPV has been shown in one study including only 37 HNSCC (Rodrigo et al,

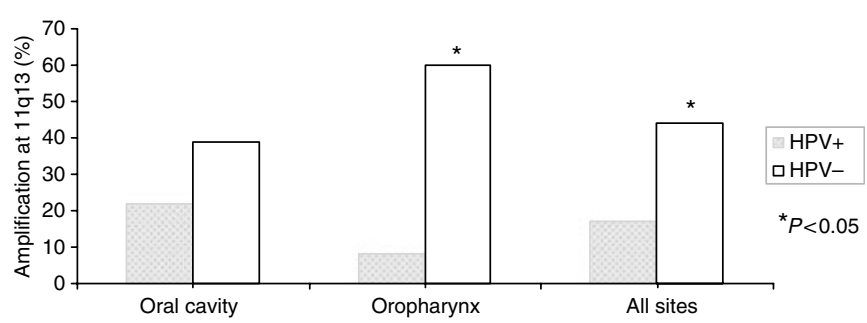

Figure I Frequency of $|\mathrm{|q}| 3 \mathrm{amp}$ according to HPV status and tumour site.

Table 3 Association of molecular markers with HPV status

\begin{tabular}{|c|c|c|c|}
\hline \multirow[b]{2}{*}{ Molecular characteristics } & \multicolumn{3}{|c|}{ Any HPV } \\
\hline & $\begin{array}{c}\text { No. positive } \\
(n=15)\end{array}$ & $\begin{array}{c}\text { No. negative } \\
(n=54)\end{array}$ & $\begin{array}{l}\text { Adjusted }^{\mathrm{a}} \\
\text { OR (95\% CI) }\end{array}$ \\
\hline \multicolumn{4}{|l|}{ I /q13 amplification status } \\
\hline Not amplified & 13 & 26 & I.O (referent) \\
\hline Amplified & 2 & 28 & $0.1(0.0-0.7)$ \\
\hline \multicolumn{4}{|l|}{ TP53 mutation status } \\
\hline Wild-type & 14 & 45 & 1.0 (referent) \\
\hline Mutant & I & 9 & $0.4(0.0-3.1)$ \\
\hline \multicolumn{4}{|l|}{ CDKN2A/p 16 expression } \\
\hline Negative & 6 & 36 & I.0 (referent) \\
\hline Positive & 9 & 18 & $3.0(0.9-9.7)$ \\
\hline \multicolumn{4}{|c|}{ Three molecular markers combined } \\
\hline Class I & 6 & 39 & I.0 (referent) \\
\hline Class II & 8 & 8 & $6.5(1.8-23.9)$ \\
\hline Class III & 1 & 7 & $0.9(0.1-8.9)$ \\
\hline
\end{tabular}

Abbreviations: $\mathrm{Cl}$, confidence interval; HPV, human papillomavirus; OR, odds ratio. ${ }^{a}$ Adjusted for age, site and stage, where appropriate. ${ }^{\text {b}}$ Three molecular markers combined were classified as: class $\|=T P 53 w t$, pl6-positive and no ||$q \mid 3$ amplification. Class III =TP53wt, p|6-positive and ||q|3 amplification. Class $\mid=$ all other possible combination of TP53 mutation status, $\mathrm{p} / 6$ expression and $\mid \mathrm{|q} / 3$ amplification status

2002). Loss of heterozygosity at TP53, 11q13 amp and HPV status were reported on only $11(30 \%)$ of their samples and p16 overexpression was not evaluated. The study reported a lower frequency of $11 \mathrm{q} 13 \mathrm{amp}$ in HPV-positive tumours (HPV + with $11 \mathrm{q} 13 \mathrm{amp}=2$ out of $4(50 \%) ; \mathrm{HPV}-$ with $11 \mathrm{q} 13 \mathrm{amp}=5$ out of 7 (71\%) but their HPV-positive tumours were more likely to have LOH at TP53 (three out of four (75\%)). Earlier studies utilising immunohistochemistry have shown that the overexpression of p53 and p16 and reduced expression of cyclin D1 were associated with HPV-positive tumours but 11q13 amp was not evaluated and these studies only included tumours arising in the tonsils (Andl et al, 1998; Li et al, 2004). One other study evaluated the combined relationship between the three molecular markers and HPV status using immunohistochemistry (Wilczynski et al, 1998), but similar to the earlier mentioned studies, their analysis was limited to tumours that arose in the tonsils. In addition, the study included tumours that were first primaries, recurrences, lymph node metastases and lung metastases. Despite the differences in sample size and tumour site included in these analyses, the results from these three studies are in agreement with our findings. In our study, the combined characteristics of TP53 mutation status, p16 protein expression (a protein which is overexpressed as a consequence of HPV E7 expression) and 11q13 amp (a genetic alteration frequently observed in head and neck tumours) were 
evaluated to further characterise the role of HPV in head and neck tumourigenesis. Tumours that were HPV-positive were more likely to carry all three markers (wild-type TP53, express p16 and no amplification at 11q13). We included in our analyses tumours that were first primaries from various sites within the oral cavity and pharynx and demonstrate that HPV-positive tumours with this distinct molecular phenotype can arise not only in the oropharynx ( $50 \%$, four out of eight) but also in the oral cavity $(50 \%$, four out of eight).

Our results shed further light on the multiple genetic alterations that are commonly found in of head and neck tumours (Gollin, 2001). A genetic progression model for HNSCC has been proposed by Califano et al (Califano et al, 1996, 2000) and describes a series of ordered genetic changes which may occur during tumour development. It is thought that, for the most part, early genetic alterations include loss of chromosomal bands 9p21,3p, 17p13 and amplification of 11q13. The candidate genes involved in these genetic alterations are thought to be $C D K N 2 A / \mathrm{p} 16$, the tumour suppressor gene FHIT, TP53 and the CCND1 oncogene, respectively. Examination of hyperplastic, dysplastic, carcinoma in situ and invasive carcinoma lesions revealed increasing $\mathrm{LOH}$ which corresponded with histopathological progression (Califano et al, 1996). Loss of heterozygosity at 9p21 was the most frequent alteration in benign hyperplastic lesions, followed by LOH at 3p21 and $17 \mathrm{p} 13$. In addition, dysplastic lesions revealed an increased incidence of allelic imbalance at 11q13 (benign hyperplasia: (6\%), dysplasia: (29\%), carcinoma in situ: $40 \%$, invasive carcinoma $(61 \%))$. Our results show that HPV-positive tumours are less likely to be amplified at $11 \mathrm{q} 13$ and at the same time p16 is overexpressed, providing indirect evidence that the infection may have occurred at an earlier time point in the carcinogenic process.

The loss of functional TP53 by mutation seems not to be necessary in HPV-positive HNSCC, as p53 protein loss results from increased degradation in these tumours (Wiest et al, 2002; Hafkamp et al, 2003; Braakhuis et al, 2004). The HPV E7 oncoprotein binds and degrades the RB1 tumour suppressor protein (Boyer et al, 1996), which in turn causes the release of E2F (a transcriptional regulator of cell proliferation genes) from $\mathrm{pRb} /$ E2F complexes, permitting E2F to transactivate S-phase-related genes. The functional inactivation of $\mathrm{pRb}$ by $\mathrm{E} 7$ leads to overexpression of the cyclin-dependent kinase inhibitor p16 (Khleif et al, 1996). The detection of p16 expression therefore is considered to be a surrogate marker for HPV infection, this observation was also confirmed in our studies.

Amplification of chromosomal band 11q13 has been reported in a number of carcinomas (head and neck, breast, lung, pancreatic, prostate, ovarian, bladder and so on.) (Schwab, 1998). Approximately $45 \%$ of HNSCC have amplification of 11q13 (Schuuring, 1995; Lese et al, 1995). The amplification status of chromosomal band 11q13 was determined in our study, using a sensitive methodology, FISH with probes for FGF3/INT2, FGF4/HST1 or CCND1 (Lese et al, 1995; Shuster et al, 2000). A significantly smaller proportion of patients with $11 \mathrm{q} 13 \mathrm{amp}$ were observed in the HPV-positive group (13\%, two out of 15$)$ compared to the HPV-negative group $(54 \%, 26$ out of 48$)$. One consequence of
$11 \mathrm{q} 13$ amp is CCND1 overexpression, which is thought to play a direct role in this disease (Callender et al, 1994). Other protooncogenes which map to the $11 \mathrm{q} 13$ core region are amplified and overexpressed (Huang et al, 2002), but their role in head and neck tumour development has not yet been fully delineated. The CCND1 gene product, cyclin D1 associates with cyclin-dependent kinase 4 and 6, and this complex promotes RB1 phosphorylation and like the HPV E7 oncoprotein, their interaction leads to the dissociation of $\mathrm{pRb}$ from the transcription factor E2F. This results in transition of the cell from $G_{1}$ into $S$-phase. One possible explanation for the lack of $11 \mathrm{q} 13$ amp in HPV-positive tumours may be that amplification of chromosomal band 11q13 might be unnecessary, as the resulting interaction of the HPV E7 oncoprotein with $\mathrm{pRb}$ might allow the cells to be less dependent on CCND1 for cell cycle progression. We therefore believe that the low frequency of $11 \mathrm{q} 13$ amp observed in our HPV-positive head and neck tumours may be explained by a distinct mechanism for HPV carcinogenesis.

Several studies report that patients with HPV-positive head and neck tumours have an improved prognosis (Ritchie et al, 2003; Schlecht, 2005), whereas amplification of $11 \mathrm{q} 13$ has been associated with a more rapid and frequent recurrence of disease (Fujii et al, 2001) and poorer survival (Akervall et al, 1997; Rodrigo et al, 2000; Namazie et al, 2002). Weinberger et al (2006) has shown that patients with HPV-positive tumours which express high levels of p16 protein and low levels of p53 protein present with a favourable prognosis. We have shown in our study that HPV-positive tumours have high levels of p16 expression and wild-type TP53 and in addition, a low frequency of amplification at 11q13. Further analyses are warranted to determine whether this lack of $11 \mathrm{q} 13 \mathrm{amp}$ also contributes to the improved prognosis observed in patients with HPV-positive HNSCC.

\section{ACKNOWLEDGEMENTS}

The authors are grateful to Drs Jonas T Johnson, Eugene N Meyers and Jennifer R Grandis for their support of this study, and Ms Robin Wagner, Ms Jennifer Vates and Ms Jennifer Ridge-Hetrick for assistance with clinical correlates. We thank Drs Jennifer Grandis and Robert Ferris for critical reading of the manuscript. We thank Jane Dudek and David Reed from Roche Diagnostics for allowing us to evaluate the LightCycler ${ }^{\circledR} 2.0$ system for use in HPV testing and for making available the HPV Linear Array reagents (an RUO product) for the HPV genotyping. We also thank Drs Ilyas Kamboh and Robert Redner for the use of their instrumentation; Ryan Minster and Dr David Sloan (Biotage) for their assistance in pyrosequencing. This work was supported in part by NIH Grants R01DE10513, R01DE12008 and R01DE14729 to SMG, P50CA097190 (SPORE: Project 1) to ET and JLW and K07CA80668 to FM. CCRR and JSW were supported by the UPCI Cancer Education and Career Development Grant R25CA089507 to William Bigbee. The FISH studies were carried out in the University of Pittsburgh Cancer Institute Cytogenetics Facility, funded in part by P30CA47904 to Ronald B Herberman.

\section{REFERENCES}

Akervall JA, Michalides RJ, Mineta H, Balm A, Borg A, Dictor MR, Jin Y, Loftus B, Mertens F, Wennerberg JP (1997) Amplification of cyclin D1 in squamous cell carcinoma of the head and neck and the prognostic value of chromosomal abnormalities and cyclin D1 overexpression. Cancer 79: $380-389$

Andl T, Kahn T, Pfuhl A, Nicola T, Erber R, Conradt C, Klein W, Helbig M, Dietz A, Weidauer H, Bosch FX (1998) Etiological involvement of oncogenic human papillomavirus in tonsillar squamous cell carcinomas lacking retinoblastoma cell cycle control. Cancer Res 58: 5-13
Blot WJ, McLaughlin JK, Winn DM, Austin DF, Greenberg RS, PrestonMartin S, Bernstein L, Schoenberg JB, Stemhagen A, Fraumeni Jr JF (1988) Smoking and drinking in relation to oral and pharyngeal cancer. Cancer Res 48: $3282-3287$

Boyer SN, Wazer DE, Band V (1996) E7 protein of human papilloma virus16 induces degradation of retinoblastoma protein through the ubiquitinproteasome pathway. Cancer Res 56: 4620-4624

Braakhuis BJ, Snijders PJ, Keune WJ, Meijer CJ, Ruijter-Schippers HJ, Leemans CR, Brakenhoff RH (2004) Genetic patterns in head and neck 
cancers that contain or lack transcriptionally active human papillomavirus. J Natl Cancer Inst 96: 998 - 1006

Califano J, van der Riet P, Westra W, Nawroz H, Clayman G, Piantadosi S, Corio R, Lee D, Greenberg B, Koch W, Sidransky D (1996) Genetic progression model for head and neck cancer: implications for field cancerization. Cancer Res 56: 2488-2492

Califano J, Westra WH, Meininger G, Corio R, Koch WM, Sidransky D (2000) Genetic progression and clonal relationship of recurrent premalignant head and neck lesions. Clin Cancer Res 6: 347-352

Callender T, El-Naggar AK, Lee MS, Frankenthaler R, Luna MA, Batsakis JG (1994) PRAD-1 (CCND1)/cyclin D1 oncogene amplification in primary head and neck squamous cell carcinoma. Cancer 74: 152-158

de Roda Husman AM, Walboomers JM, van den Brule AJ, Meijer CJ, Snijders PJ (1995) The use of general primers GP5 and GP6 elongated at their $3^{\prime}$ ends with adjacent highly conserved sequences improves human papillomavirus detection by PCR. J Gen Virol 76(Part 4): $1057-1062$

Franceschi S, Levi F, La VC, Conti E, Dal ML, Barzan L, Talamini R (1999) Comparison of the effect of smoking and alcohol drinking between oral and pharyngeal cancer. Int J Cancer 83: 1-4

Franceschi S, Talamini R, Barra S, Baron AE, Negri E, Bidoli E, Serraino D, La VC (1990) Smoking and drinking in relation to cancers of the oral cavity, pharynx, larynx, and esophagus in northern Italy. Cancer Res 50: $6502-6507$

Fujii M, Ishiguro R, Yamashita T, Tashiro M (2001) Cyclin D1 amplification correlates with early recurrence of squamous cell carcinoma of the tongue. Cancer Lett 172: 187-192

Gillison ML, Koch WM, Capone RB, Spafford M, Westra WH, Wu L, Zahurak ML, Daniel RW, Viglione M, Symer DE, Shah KV, Sidransky D (2000) Evidence for a causal association between human papillomavirus and a subset of head and neck cancers. J Natl Cancer Inst 92: $709-720$

Gollin SM (2001) Chromosomal alterations in squamous cell carcinomas of the head and neck: window to the biology of disease. Head Neck 23: $238-253$

Gravitt PE, Peyton CL, Alessi TQ, Wheeler CM, Coutlee F, Hildesheim A, Schiffman MH, Scott DR, Apple RJ (2000) Improved amplification of genital human papillomaviruses. J Clin Microbiol 38: 357-361

Hafkamp HC, Speel EJ, Haesevoets A, Bot FJ, Dinjens WN, Ramaekers FC, Hopman AH, Manni JJ (2003) A subset of head and neck squamous cell carcinomas exhibits integration of HPV 16/18 DNA and overexpression of p16INK4A and p53 in the absence of mutations in p53 exons 5-8. Int $J$ Cancer 107: $394-400$

Herrero R, Castellsague X, Pawlita M, Lissowska J, Kee F, Balaram P, Rajkumar T, Sridhar H, Rose B, Pintos J, Fernandez L, Idris A, Sanchez MJ, Nieto A, Talamini R, Tavani A, Bosch FX, Reidel U, Snijders PJ, Meijer CJ, Viscidi R, Munoz N, Franceschi S (2003) Human papillomavirus and oral cancer: the International Agency for Research on Cancer multicenter study. J Natl Cancer Inst 95: 1772 - 1783

Huang X, Gollin SM, Raja S, Godfrey TE (2002) High-resolution mapping of the 11q13 amplicon and identification of a gene, TAOS1, that is amplified and overexpressed in oral cancer cells. Proc Natl Acad Sci USA 99: $11369-11374$

Khleif SN, DeGregori J, Yee CL, Otterson GA, Kaye FJ, Nevins JR, Howley PM (1996) Inhibition of cyclin D-CDK4/CDK6 activity is associated with an E2F-mediated induction of cyclin kinase inhibitor activity. Proc Natl Acad Sci USA 93: 4350-4354

Law JC, Whiteside TL, Gollin SM, Weissfeld J, El-Ashmawy L, Srivastava S, Landreneau RJ, Johnson JT, Ferrell RE (1995) Variation of p53 mutational spectra between carcinoma of the upper and lower respiratory tract. Clin Cancer Res 1: 763-768

Lese CM, Rossie KM, Appel BN, Reddy JK, Johnson JT, Myers EN, Gollin SM (1995) Visualization of INT2 and HST1 amplification in ora squamous cell carcinomas. Genes Chromosomes Cancer 12: 288-295

Li W, Thompson CH, Cossart YE, O'Brien CJ, McNeil EB, Scolyer RA, Rose BR (2004) The expression of key cell cycle markers and presence of human papillomavirus in squamous cell carcinoma of the tonsil. Head Neck 26: 1-9

Merletti F, Boffetta P, Ciccone G, Mashberg A, Terracini B (1989) Role of tobacco and alcoholic beverages in the etiology of cancer of the oral cavity/oropharynx in Torino, Italy. Cancer Res 49: 4919-4924

Namazie A, Alavi S, Olopade OI, Pauletti G, Aghamohammadi N, Aghamohammadi M, Gornbein JA, Calcaterra TC, Slamon DJ, Wang MB, Srivatsan ES (2002) Cyclin D1 amplification and p16(MTS1/CDK4I) deletion correlate with poor prognosis in head and neck tumors. Laryngoscope 112: 472-481

Ritchie JM, Smith EM, Summersgill KF, Hoffman HT, Wang D, Klussmann JP, Turek LP, Haugen TH (2003) Human papillomavirus infection as a prognostic factor in carcinomas of the oral cavity and oropharynx. Int $J$ Cancer 104: $336-344$

Rodrigo JP, Garcia LA, Ramos S, Lazo PS, Suarez C (2000) EMS1 gene amplification correlates with poor prognosis in squamous cell carcinomas of the head and neck. Clin Cancer Res 6: 3177-3182

Rodrigo JP, Gonzalez MV, Lazo PS, Ramos S, Coto E, Alvarez I, Garcia LA, Suarez C (2002) Genetic alterations in squamous cell carcinomas of the hypopharynx with correlations to clinicopathological features. Oral Oncol 38: 357-363

Saiki RK, Bugawan TL, Horn GT, Mullis KB, Erlich HA (1986) Analysis of enzymatically amplified beta-globin and HLA-DQ alpha DNA with allelespecific oligonucleotide probes. Nature 324: $163-166$

Schlecht NF (2005) Prognostic value of human papillomavirus in the survival of head and neck cancer patients: an overview of the evidence. Oncol Rep 14: 1239-1247

Schraml P, Kononen J, Bubendorf L, Moch H, Bissig H, Nocito A, Mihatsch MJ, Kallioniemi OP, Sauter G (1999) Tissue microarrays for gene amplification surveys in many different tumor types. Clin Cancer Res 5: $1966-1975$

Schuuring E (1995) The involvement of the chromosome 11q13 region in human malignancies: cyclin D1 and EMS1 are two new candidate oncogenes - a review. Gene 159: 83-96

Schwab M (1998) Amplification of oncogenes in human cancer cells. Bioessays 20: $473-479$

Shuster MI, Han L, Le Beau MM, Davis E, Sawicki M, Lese CM, Park NH, Colicelli J, Gollin SM (2000) A consistent pattern of RIN1 rearrangements in oral squamous cell carcinoma cell lines supports a breakage-fusionbridge cycle model for 11q13 amplification. Genes Chromosomes Cancer 28: $153-163$

Sidransky D (1995) Molecular genetics of head and neck cancer. Curr Opin Oncol 7: 229-233

Smith EM, Hoffman HT, Summersgill KS, Kirchner HL, Turek LP, Haugen TH (1998) Human papillomavirus and risk of oral cancer. Laryngoscope 108: $1098-1103$

Syrjanen K, Syrjanen S, Lamberg M, Pyrhonen S, Nuutinen J (1983) Morphological and immunohistochemical evidence suggesting human papillomavirus (HPV) involvement in oral squamous cell carcinogenesis. Int J Oral Surg 12: 418-424

Weber A, Wittekind C, Tannapfel A (2003) Genetic and epigenetic alterations of $9 \mathrm{p} 21$ gene products in benign and malignant tumors of the head and neck. Pathol Res Pract 199: 391-397

Weinberger PM, Yu Z, Haffty BG, Kowalski D, Harigopal M, Brandsma J, Sasaki C, Joe J, Camp RL, Rimm DL, Psyrri A (2006) Molecular classification identifies a subset of human papillomavirus-associated oropharyngeal cancers with favorable prognosis. J Clin Oncol 24: $736-747$

Wiest T, Schwarz E, Enders C, Flechtenmacher C, Bosch FX (2002) Involvement of intact HPV16 E6/E7 gene expression in head and neck cancers with unaltered p53 status and perturbed pRb cell cycle control. Oncogene 21: $1510-1517$

Wilczynski SP, Lin BT, Xie Y, Paz IB (1998) Detection of human papillomavirus DNA and oncoprotein overexpression are associated with distinct morphological patterns of tonsillar squamous cell carcinoma. Am J Pathol 152: 145-156 